University of Nebraska - Lincoln

DigitalCommons@University of Nebraska - Lincoln

$2-1980$

\title{
The Extrafloral Nectaries of Ipomoea leptophylla (Convolvulaceae)
}

Kathleen H. Keeler

University of Nebraska - Lincoln, kkeeler1@unl.edu

Follow this and additional works at: https://digitalcommons.unl.edu/bioscifacpub

Part of the Botany Commons

Keeler, Kathleen H., "The Extrafloral Nectaries of Ipomoea leptophylla (Convolvulaceae)" (1980). Faculty Publications in the Biological Sciences. 280.

https://digitalcommons.unl.edu/bioscifacpub/280

This Article is brought to you for free and open access by the Papers in the Biological Sciences at DigitalCommons@University of Nebraska - Lincoln. It has been accepted for inclusion in Faculty Publications in the Biological Sciences by an authorized administrator of DigitalCommons@University of Nebraska - Lincoln. 


\title{
THE EXTRAFLORAL NECTARIES OF IPOMOEA LEPTOPHYLLA (CONVOLVULACEAE) ${ }^{1}$
}

\author{
KATHLEen H. KeEler \\ School of Life Sciences, University of Nebraska, Lincoln, Nebraska 68588
}

\section{A B S T R A C T}

\begin{abstract}
Ipomoea leptophylla Torr. (Convolvulaceae) is a sprawling dry-site morning glory with two types of extrafloral nectaries: foliar nectaries and nectaries on the outside of the sepals. Both are shown to greatly increase insect visitation to the plant. Ants visiting sepal-surface nectaries significantly decrease flower damage caused by grasshoppers and seed losses caused by bruchids. These results are similar to those for $I$. carnea and other plants whose extrafloral nectary-ant interactions have been studied, but differ in detail. This is the first demonstration of antiherbivore defense of a prairie plant by nectary visitors.
\end{abstract}

EXTRAFLORAL nectaries (EFNs) are nectarsecreting glands on a plant which do not function in pollination. They are distinguished from hydathodes, resin glands, and other structures, by the secretion of aqueous sugar solution, almost invariably containing amino acids (Baker and Baker, 1973; Bentley, 1977a; Baker, Opler and Baker, 1978). Recent studies of the function of EFNs have generally supported the theory that they are one of the plant's defenses against herbivores. An ant-plant mutualism occurs at the EFNs: the plant derives protection from the actions of the ants (predation on other insects or defense of the nectary) while the ants receive food (nectar with its carbohydrates and amino acids) (Elias and Gelband, 1975; Bentley, 1976, 1977a,b; Keeler, 1977; Schemske, 1978; Tilman, 1978; Inouye and Taylor, 1979; Pickett and Clark, 1979).

In different plant species, EFNs have been shown to provide different defensive functions. These include defense of leaves from damage (Bentley, 1976, 1977b; Keeler, 1977; Tilman, 1978), reduction of flower-robbing (Elias and Gelband, 1975; Keeler, 1977), and decreased seed loss (Bentley, 1976; Schemske,

${ }^{1}$ Received for publication 11 April 1978; revision accepted 17 July 1979.

I thank Dr. B. C. Ratcliffe, University of Nebraska State Museum, for identifying the majority of the insects. I thank J. Ballard, Dept. Entomology, University of Nebraska for identifying the ants, Dr. W. E. LaBerge, Illinois Insect Survey for identifying the pollinators and Dr. C. D. Johnson, Northern Arizona University, Flagstaff, for identifying the bruchid. Dr. K. W. Lee, School of Life Sciences, University of Nebraska made the electronmicrographs. I especially want to thank Irene Baker, Botany Department, University of California-Berkeley, who performed the nectar analyses between trips on three continents.

I appreciate the cooperation of the Cedar Point Biological Station staff and the use of C.P.B.S. facilities. This work was funded by a University of Nebraska Maude Hammond Fling Faculty Fellowship and travel supported by NSF \#SER 77-06931.
1978; Inouye and Taylor, 1979; Pickett and Clark, 1979). The plants in these studies are species from lowland seasonal and aseasonal tropical environments, eastern North America, the arid southwestern U.S., and high elevations in the Rocky Mountains. The families included are diverse: Asteraceae, Bignoniaceae, Bixaceae, Cactaceae, Convolvulaceae, Rosaceae and Zingiberaceae.

The purpose of this study was to determine the function of the EFNs of I. leptophylla Torr. (Convolvulaceae). This is the first study of the EFNs of a prairie plant and the first investigation of the function of EFNs in a second member of a previously studied genus.

MATERIALS AND METHODS-Ipomoea leptophylla (Fig. 1) is a sprawling morning glory native to the high plains of North America (Texas and Arizona to South Dakota and Montana). The plant is a deeply rooted perennial with narrow, linear leaves and a large roottuber. The flowers are red-purple, open in the morning, and last only a single day.

Ipomoea leptophylla was studied in the summer of 1977 and 1978 in Keith Co., Nebraska, near the University of Nebraska Cedar Point Biological Station. Plant-insect interactions were observed in the field. Nectary visitors were collected and identified in June and July, 1978 , by recording the insects present on 1,000 plants. In the very dry June of $1978,95 \%$ of the I. leptophylla plants in Keith and Arthur counties aborted their buds. Flowering was successful only on the wettest sites: these are the source of the sepal nectary and flower data.

Nectar was collected from sepal and floral nectaries onto Whatman \#1 filter paper and analyzed for chemical content by I. Baker (Baker and Baker, 1973; 1975; 1976a,b). Foliar nectar was not obtained.

The major leaf-, flower-, and seed-damaging 
insects were identified. Damage to I. leptophylla plants was compared between ant-visited and ant-free plants. The plants without ants were in a dry watercourse which lacked nest sites for ants. In one population, plants were monitored for natural frequency of ant visitors, which was recorded as classes of ant activity. The relationship between levels of ant abundance and seed production was analyzed. Ant-exclusion experiments proved impossible because of the sprawling shape of the plant and toxicity of resins (e.g., Tanglefoot) to I. leptophylla foliage.

Results-Foliar nectaries-Ipomoea leptophylla has foliar nectaries on the underside of the lamina, not far above the junction with the petiole (Fig. 5). The lamina in I. leptophylla appears to have extended down the petiole to incorporate the nectary site, since these nectaries are presumably homologous with petiolar nectaries in other Ipomoea species (Keeler and Kaul, 1979). The foliar nectary is extremely small and inconspicuous, consisting only of a concentration of capitate trichomes.

Only the earliest leaves of the year secrete nectar. Ipomoea leptophylla bolts in late June, emerging with leaves that are distinctly broader than those produced in subsequent growth. Thirty early leaves had a mean width of 0.63 $\mathrm{cm}(\mathrm{SD}=0.10)$, while 27 late leaves had a mean width of $.25 \mathrm{~cm}(\mathrm{SD}=0.10)$. These mean differences are statistically significant $(\mathrm{t}=$ 14.3 , df $=55, P \ll 0.001)$. June 1978 , when these data were collected, was exceptionally dry. In wetter years the difference between early and late leaves may be less marked, although this seems unlikely from observations in previous years.

The differences in early and late leaves were reflected in differences in nectar feeder frequencies on plants with these types of leaves. Non-flowering plants with early leaves (June 1978) had nectar feeding insects on 771 of 1,000 plants; non-flowering plants with late leaves (July 1978) had nectar feeders on 47 (4.8\%) of 996 plants. This difference is statistically significant $\left(\chi^{2}=1079\right.$, df $\left.=1, P \ll 0.001\right)$.

Sepal nectaries - I. leptophylla has a second set of EFNs around the lower, external edge of the sepals (Fig. 6). (Sepal nectaries are on part of the flower. However, they are termed extrafloral here because they do not contribute to pollinator attraction.) The sepal nectaries begin producing nectar when the buds are small (less than $0.5 \mathrm{~cm}$ long) and continue as the flower develops and opens, and while the fruit matures. Nectar production ceases as the capsule dries out. Nectar production ranges from
$0.1 \mu \mathrm{l}$ to $0.7 \mu \mathrm{l}$ per nectary per day, with a mean of $0.3(\mathrm{~N}=37)$.

Chemical analysis of Ipomoea leptophylla sepal nectar indicated the presence of some organic acids but no lipids, phenolics, or protein. The sugars present were glucose $(58.6 \%)$ and fructose $(41.4 \%)$; no sucrose or other sugars was detected. The amino acid composition is given in Table 1 .

Floral nectaries-The red-purple flowers open at dawn and wilt by noon, lasting a little longer if the weather is cool. Relatively large amounts of nectar are produced-as much as $9 \mu \mathrm{l}$ from a single flower. Floral nectar lacked lipids, protein and organic acids, but very slight quantities of phenolics were present. Sugars present were glucose $(40.0 \%)$, fructose $(36.4 \%)$ and sucrose $(23.6 \%)$. The amino acids present are given in Table 1.

Plant defense-The idea that EFNs protect the plant (Belt, 1874; Delpino, 1886-9; Bentley, 1977a) was considered by comparing natural levels of plant damage and insect visitors.

Chief causes of damage to I. leptophylla foliage were the beetles Chelymorpha cassidea (Fabr.) and Metriona sp. (Chrysomelidae) which attack stems and leaves, especially in June. Linsley (1960) observed C. cassidea and M. bicolor (Fabr.) infesting I. leptophylla foliage in New Mexico. The foliage received little other damage. Even "outbreak" numbers of grasshoppers rarely caused more than $10 \%$ leaf injury. Cattle avoid I. leptophylla, often to such a degree that it remains as a dominant in overgrazed pastures.

The floral tissue is more palatable. Grasshopper damage to flowers approached $100 \%$ consumption of corollas by midday at some sites. An adult grasshopper could consume the $6 \mathrm{~cm}$ corolla in an hour (A. Joern, pers. comm.). Beetles and walking sticks also occasionally destroyed flowers.

The ovaries were attacked by a larval lepidopteran. This caterpillar moved from bud or flower to bud or flower, consuming only the ovary. It has not been possible to identify it without an adult, but based on larval characteristics it is Heliophana (Noctuidae) (Fig. 3).

Like many Ipomoea species, I. leptophylla has a bruchid seed predator, Megacerus discoidus (Say). This species deposits eggs on developing fruit of I. leptophylla; the larvae develop within the capsule, consuming one or more seeds. Up to $77 \%$ of a plant's seed crop have been observed to be infested by $M$. discoidus.

Type and frequency of insect visitors to plants was monitored by means of three sur- 

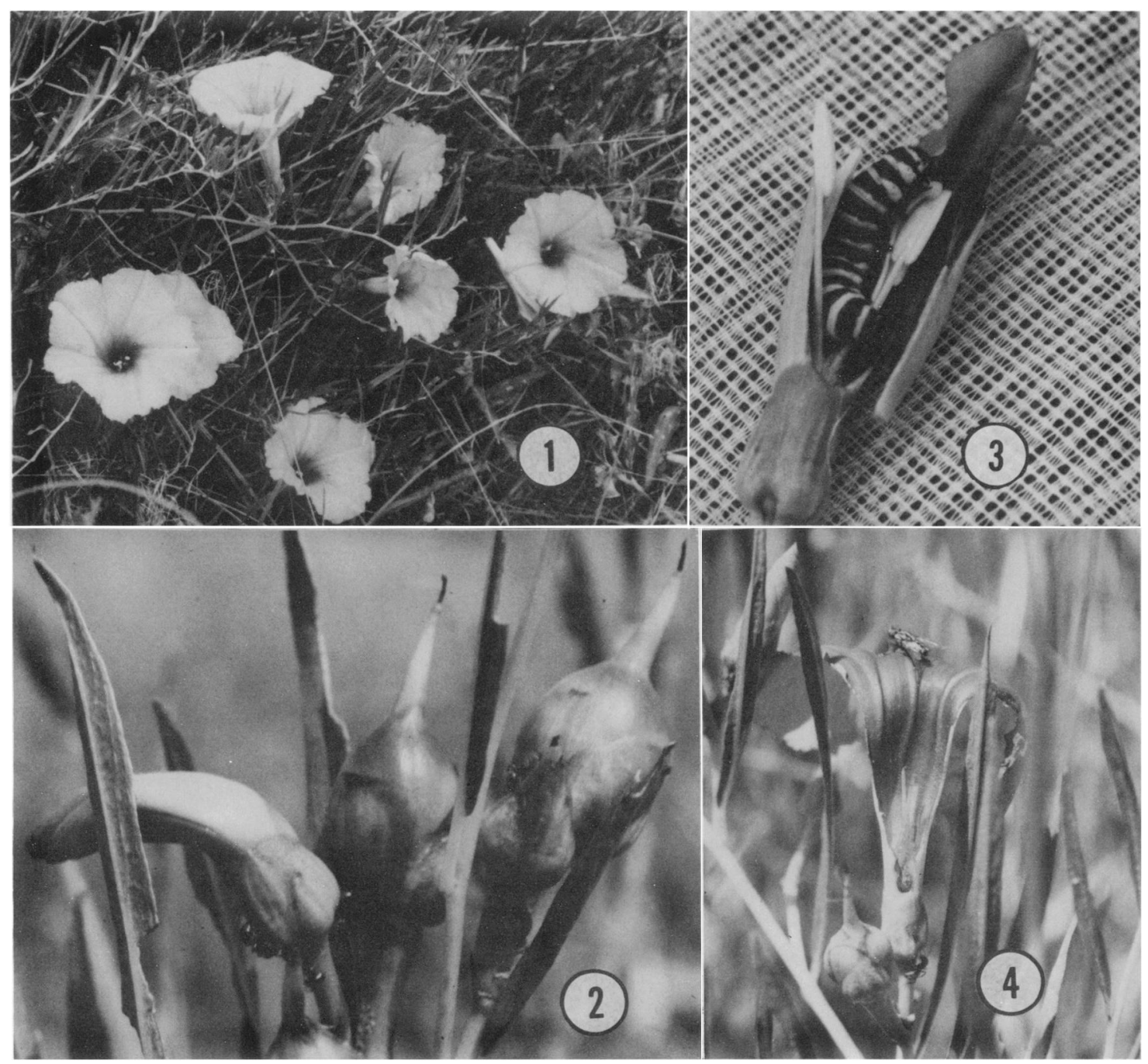

Fig. 1-4. 1. Ipomoea leptophylla Torr., bush morning glory. $\times 0.2$. 2. Ants visiting $I$. leptophylla sepal nectaries. $\times$ 1.0. 3. Heliophana sp. in I. leptophylla. Bud opened for photograph. $\times 1.6$. 4. Grasshopper-damaged I. leptophylla flowers. Note destruction of stigma. $\times 0.8$.

veys: 1) early in the season when the plants had foliar nectaries but no sepal nectaries, 2) during flowering when sepal nectaries were active and after foliar nectaries had senesced, and 3) on plants which, as a result of the dry conditions, had aborted their flowers and had no functioning nectaries.

Insects were present on $51.1 \%(511 / 1,000)$ of the plants with only foliar nectaries, on $90.7 \%(635 / 700)$ of the plants with only sepal nectaries active, and on $6.6 \%(76 / 996)$ of the plants with no functioning nectaries. Potential nectar feeders were 771 of the $838(92.0 \%)$ insects on the plants with active foliar nectaries, 4,355 of the $4,462(97.6 \%)$ insects on the plants with active sepal nectaries, and 47 of the 76 $(61.8 \%)$ insects on the plants with no active nectaries.
On plants with functional nectaries, ants made up the largest group of visitors: $49.9 \%$ of the visitors to plants with foliar nectaries, and $96.0 \%$ of the visitors to plants with active sepal nectaries (Fig. 2). The next largest taxon in the former case was beetles $(31.2 \%)$, in the latter case flies $(1.4 \%)$. The situation was quite different on plants without nectaries: the most common group of insects was beetles $(39.4 \%$ of all plant visitors), various predators were second $(32.9 \%)$ with ants a distant third $(20.0 \%)$. The first survey was early in the season while the second two surveys, of plants with sepal nectaries and plants without nectaries, were carried out concurrently.

Plants with sepal nectaries sometimes had open flowers. However, flower visitors differed greatly from extrafloral nectary visitors. 


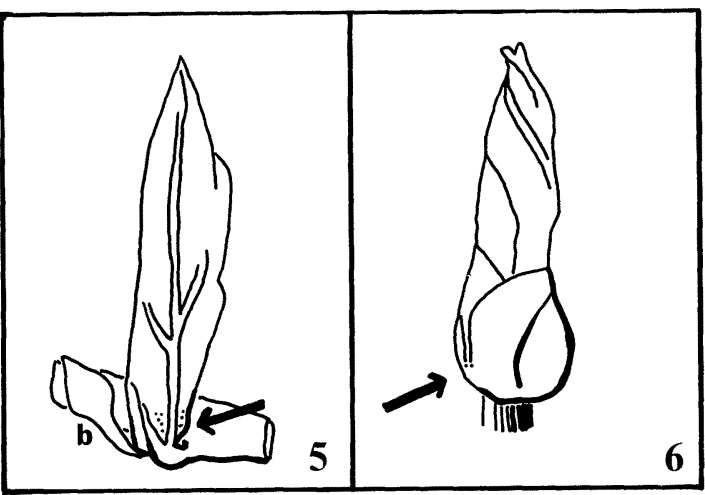

Fig. 5, 6. 5. Site of Ipomoea leptophylla foliar nectaries. b, bud. $\times .75$. 6. Location of I. leptophylla sepal nectaries. $\times 0.5$.

Flower visitors included Melitoma grisella (Cockerell and Porter), Melissodes agilis Cresson, Svasta obliqua obliqua (Say) and Agapostemon texanus Cresson, which are believed to be pollinators. Linsley (1960) reports similar observations. None of these species was ever observed on the foliage or at the extrafloral nectaries.

Megacerus discoidus was also found inside the flowers. Its purpose there is not known but it has been frequently observed (C. D. Johnson, pers. comm.). It appears to feed on sepal nectar, although much of its activity in the vicinity of the sepal nectaries may be related to oviposition rather than feeding.

Grasshoppers, walking sticks, and large beetles (Eleodes sp., Tenebrionidae) found inside the flower were intent on consuming it.

The ant species visiting Ipomoea leptophylla were Pheidole bicarinata bicarinata Mayr (30.0\% of all ants seen); Formica microgyna group (29.4\% of all ants seen); Crematogaster lineolata (Say) (9.4\% of all ants seen); Formica rufa group oreas Wheeler (9.2\%); Formica fusca group cinerea lepida Wheeler (8.3\%); Pheidole bicarinata longula Emery, Lasius neoniger Emery, Myrmica americana Weber, Formica schaufussi Mayr, Dorymyrmex pyramicus (Roger) (between 1 and 5\%), and a number of species at less than $1 \%$ of the visitors.

It is possible that foliar nectaries function to protect the leaves. However, the low levels of herbivory suggest the leaves are amply physically or chemically protected, probably by their high latex content. If operative, protection of leaves must occur only early in the season as in Prunus (Tilman, 1978). Possibly, the function of leaf nectaries is not protection but some other role such as habituation of ants
TABLE 1. Amino acid content of Ipomoea leptophylla sepal and floral nectar. Proportion of each

\begin{tabular}{lcc}
\hline \hline & Sepal nectar & Floral nectar \\
\hline alanine & .1060 & .0354 \\
arginine & .0345 & .0366 \\
asparagine & .1160 & .1322 \\
aspartic & .0221 & .0401 \\
cysteine, etc. & .0398 & .0378 \\
glutamic & .0707 & .0638 \\
glutamine & .0424 & .0756 \\
glycine & .0353 & .1181 \\
histidine & $\mathrm{ND}$ & $\mathrm{ND}$ \\
isoleucine & .0353 & .1086 \\
leucine & $\mathrm{ND}$ & $\mathrm{ND}$ \\
lysine & $\mathrm{ND}$ & .0992 \\
methionine & $\mathrm{ND}$ & $\mathrm{ND}$ \\
phenylalanine & .0893 & $\mathrm{ND}$ \\
proline & .0177 & .0047 \\
serine & .1325 & .0850 \\
threonine & .0618 & .0472 \\
tryptophan & $\mathrm{ND}$ & $\mathrm{ND}$ \\
tyrosine & $\mathrm{ND}$ & .0425 \\
valine & .0960 & $\mathrm{ND}$ \\
ornithine (?) & $\mathrm{ND}$ & .0732 \\
unidentified & $\mathrm{ND}$ & 2 \\
Total amino acid & & \\
concentration & & 182 \\
$\mu$ gm/ml & $121-242$ & \\
\hline
\end{tabular}

Method of Baker and Baker (1973, 1976). Determined by Irene Baker.

$\mathrm{ND}=$ not detected.

to the plants in anticipation of the appearance of flowers.

Since the sepal nectaries produced large quantities of nectar and attracted abundant insects, these were considered the important site of ant defense. Situated at the base of the flower, sepal nectaries would seem to be involved in maximizing seed reproduction. The three organisms that were important causes of seed loss (grasshoppers, Megacerus discoidus, and the noctuid larva, Heliophana) were considered in terms of their success in ant-visited and ant-free areas.

Grasshoppers generally confined themselves to flower tissue, eating corolla, anthers and stamens. The effect of ants in reducing grasshopper damage to corolla tissue was studied. Some damage to the corolla was tolerable since the pollinating bees would enter even badly damaged corollas. However, total removal of the corolla removed all signals to the pollinator. Destruction of stigma and style certainly blocked pollination: none of 8 flowers whose stigmas were removed by grasshoppers developed seeds (Fig. 4). The results of comparing plants on sites without ants (from a dry watercourse) to ant-visited plants showed a statistically significant increase in corolla dam- 
TABLE 2. Effect of ant abundance on corolla damage due to grasshoppers

\begin{tabular}{lcc}
\hline \hline & $\begin{array}{c}\text { \# flowers } \\
\text { with no } \\
\text { serious } \\
\text { damage }^{\mathrm{a}}\end{array}$ & $\begin{array}{c}\text { \# flowers } \\
\text { with serious } \\
\text { damage }\end{array}$ \\
\hline $\begin{array}{l}\text { No ants present } \\
\text { Ants present on plant }\end{array}$ & $\begin{array}{c}36 \\
198\end{array}$ & 102 \\
Total flowers & $\frac{182}{234}$ & $\frac{184}{284}$
\end{tabular}

$\chi^{2}=27.67, \mathrm{df}=1, P \ll 0.001$.

a Serious damage defined as destruction of at least the stigma.

${ }^{b}$ No ants found on plant in a series of observations on different days.

age in the absence of ants (Table 2). Since badly damaged flowers do not produce seed, this difference is evolutionarily important.

A second cause of seed destruction was by the bruchid, Megacerus discoidus. Plants with abundant ants would be expected to lose fewer seeds to bruchids because the foraging ants disturb the ovipositing adults, take adults as prey (if they can catch them) or collect eggs as prey. Certainly $M$. discoidus adults were more conspicuous on ant-free plants than where ants were abundant, as were all nonants. The individuals observed in oviposition were on low-ant plants.

The results of comparing seed success in antvisited and ant-free plants is given in Table 3. Bruchids destroyed $34.2 \%$ of the seeds of plants on which ants were never seen, but only $23.4 \%$ of the seeds on plants visited by ants. This difference is statistically significant $\left(\chi^{2}=\right.$ 8.73 , df $=1, P \ll 0.005$ ).

The presence of one or more pyralid larvae on plants with and without ants was investigated. Of antless plants, 9 of $16(56 \%)$ had at least one caterpillar. Larvae were found on 68
TABLE 3. Effect of ant abundance on presence of bruchid larvae [Megacerus discoidus (Say)] in seeds of Ipomoea leptophylla

\begin{tabular}{lcc}
\hline \hline & $\begin{array}{c}\text { Number of good } \\
\text { seed }\end{array}$ & $\begin{array}{c}\text { Number of seeds } \\
\text { destroyed by bruchids }\end{array}$ \\
\hline No ants & 98 & 51 \\
Ants & $\underline{2,678}$ & $\underline{831}$ \\
Total & 2,776 & 882 \\
\hline
\end{tabular}

$\chi^{2}=8.73, \mathrm{df}=1, P \ll 0.005$.

a No ants found in a series of observations on different days.

of 94 plants $(72 \%)$ visited by ants. This difference is not significant $\left(\chi^{2}=1.00, \mathrm{df}=1\right.$, $0.50<P<0.10)$.

Another approach used was to consider seed success of individual plants without regard to specific causes of seed damage. In one study, the total seed production of a series of plants was counted after harvesting the plants. The seed sets of antless plants and ant-visited plants were compared. The seed set for the ant-visited plants was very much greater than that of non-visited plants (Table 4). Since in this particular sample plant size (vegetative biomass) of the ant-free plants was significantly greater than that of the ant-visited plants harvested (and size may be related to seed production), a subsample of the six largest antvisited plants was compared with the six nonvisited plants. Plant size in these two groups was not significantly different $(\mathrm{t}=1.01, \mathrm{df}=$ $10,0.40<P<0.20)$. Mean seed success (\% good seed) and total number of seeds produced were both significantly greater in the ant-visited plants (Table 4,B).

A second look at the relation of ant visitation to number of seeds produced was conducted by following 189 plants on a wet site throughout

TABLE 4. Relationship of ant visitation to seed set

\begin{tabular}{|c|c|c|c|c|c|}
\hline & $\begin{array}{l}\text { Number of } \\
\text { good seed }\end{array}$ & $\begin{array}{l}\text { Total seed } \\
\text { production }\end{array}$ & $\begin{array}{c}\text { Number of } \\
\text { plants }\end{array}$ & $\begin{array}{c}\bar{x} \text { dry weight/ } \\
\text { plant }^{\mathrm{a}}(\mathrm{g})\end{array}$ & $\begin{array}{c}\bar{x} \text { seed } / \\
\text { plant }\end{array}$ \\
\hline \multicolumn{6}{|l|}{ A. All plants } \\
\hline No ants present ${ }^{b}$ & $95^{c}$ & 271 & 6 & $701.8^{\mathrm{d}}$ & \\
\hline Ants present & $2,111^{\mathrm{c}}$ & 3,595 & 17 & $294.3^{d}$ & \\
\hline \multicolumn{6}{|l|}{ B. Largest plants } \\
\hline No ants present & $95^{\mathrm{e}}$ & 271 & 6 & $701.8^{f}$ & $45.2^{\mathrm{g}}$ \\
\hline Ants present & $1,479^{\mathrm{e}}$ & 2,419 & 6 & $452.7^{f}$ & $403.2^{\mathrm{g}}$ \\
\hline
\end{tabular}

a Weight of all vegetative, aboveground parts.

${ }^{b}$ No ants found in a series of observations on different days.

c These values are significantly different; $\chi^{2}=58.6$, df $=1, P \ll 0.005$.

d These values are significantly different: $\mathrm{t}=3.36$, $\mathrm{df}=21,0.01<P<0.001$.

e These values are significantly different: $\chi^{2}=68.3$, df $=1, P \ll 0.005$.

f These values are not significantly different: $\mathrm{t}=1.02, \mathrm{df}=10,0.40<P<0.20$.

g These values are significantly different: $\mathrm{t}=4.53$, df $=10, P \sim 0.001$. 
the growing season. Ant visitation to each plant was observed and recorded weekly. Seeds produced and seeds lost were counted. The regression of ant abundance (an index summing all the visitation observations) on seed set was statistically significant $(\mathrm{r}=.21, \mathrm{df}=187, P=$ 0.05 ) although the correlation was low. I take this to mean that although the presence of ants had a significant influence on seed set at this site, it was a minor effect compared to other factors. This result seems very reasonable given the drought conditions which caused all the plants at most other sites to abort their flowers, and undoubtedly influenced seed production at this site.

Discussion-Ipomoea leptophylla has two sets of nectaries that are not involved in pollination, one on the underside of leaves early in the season and one on the sepals.

The structure of Ipomoea leptophylla EFNs is similar to the structure of I. carnea EFNs (Keeler and Kaul, 1979). Minor nectar constituents are similar in both species, although I. leptophylla floral nectar lacks organic acids which are present in all the other nectars. The sepal nectar of I. leptophylla lacks sucrose; $I$. carnea sepal (= pedicellar) nectar is $35.8 \%$ sucrose (Keeler, 1977). The sugars in I. leptophylla and I. carnea floral nectar are the same, but the proportions differ, I. carnea containing $29.1 \%$ glucose, $16.1 \%$ fructose and $54.8 \%$ sucrose (Keeler, 1977).

The amino acid differences are dramatic. The sepal nectaries of I. leptophylla contain 14 amino acids; $I$. carnea sepal nectar has four amino acids (arg, asp, glu and ser; Keeler, 1977). All four of these are present in I. leptophylla nectar (Table 1) but they are not the four most abundant amino acids. Baker, Opler, and Baker (1978) reported the amino acid composition of Ipomoea alba (a night blooming, perennial, tropical species) and I. meyeri (a matinal, annual, tropical species). The former contained 10 common amino acids and 1 nonprotein amino acid, the latter only 5 common amino acids. In both cases there is some similarity and some difference from I. carnea and I. leptophylla. All four species share only arginine and serine. Thus of the four species in the genus studied, I. leptophylla has the greatest diversity of amino acids in its sepal nectar. It is by no means the most diverse nectar known, however (Baker et al., 1978).

The floral nectar of I. leptophylla also contains more amino acids than does $I$. carnea floral nectar (Keeler, 1977). All I. carnea amino acids are found in I. leptophylla, but in different proportions. Ipomoea alba floral nectar contained 12 amino acids (Baker et al.,
1978), some of which differ from I. leptophylla. In terms of amino acid content, the temperate species has the most complex nectar. Considering that both $I$. leptophylla and I. carnea have matinal flowers pollinated by oligolectic bees, it is surprising that their amino acid compositions are so different and that the nightblooming, hawkmoth-pollinated $I$. alba is intermediate.

Evidence indicates that sepal nectary visitors contribute significantly to seed production. This is the first demonstration of defense of a prairie plant by EFN visitors. The function of the foliar nectaries is not known, although they definitely enhance insect visitation to the plant.

The pattern of defense is similar to that for other species investigated where seed set was shown to be improved by ant presence (Bentley, 1977b; Schemske, 1978; Inouye and Taylor, 1979; Pickett and Clark, 1979) and different from others where flower robbing was decreased (Elias and Gelband, 1975; Keeler, 1977), or where foliage damage was reduced (Bentley, 1977b; Tilman, 1978).

Function of EFNs in I. leptophylla appears to be different from EFN function in I. carnea (Keeler, 1977). Both species are placed in the same section of the genus (Eriospermum) by Austin (1975; unpubl.). Both have foliar and sepal nectaries. However, I. carnea's foliar nectaries are on the petiole (the usual condition in Ipomoea, Keeler and Kaul, 1979) and they function in all healthy leaves; I. leptophylla's homologous nectaries are on the lamina and they are only present on the first leaves of the season. Ipomoea leptophylla is the only Ipomoea species known with transitory foliar nectaries (Keeler and Kaul, 1979); other species of similar habitat are likely to exhibit them. Keeler (1977) showed that ant visitors to $I$. carnea could decrease leaf damage from attacks by acacia ants: no similar source of injury exists for I. leptophylla.

Sepal nectaries on the two species are comparable. However, I. carnea sepal nectaries were shown to attract ants which reduced flower robbing by large bees (Xylocopa spp.) (van der Pijl, 1954; Keeler, 1977). Flower robbing has not been observed in the I. leptophylla populations studied. Ipomoea leptophylla sepal nectaries were shown to significantly decrease frequency of losses to grasshoppers (an insignificant cause of leaf damage in I. carnea; Keeler, 1975) and bruchid predation. A similar bruchid, Megacerus alternatus Bridwell was recovered from $I$. carnea seeds by Keeler (1977), and Janzen (1975) reported M. leucospilus from $I$. carnea $(=I$. fistulosa) seeds in the same area. An inverse relationship between 
EFN visitors and bruchids has been shown for I. leptophylla but not for I. carnea.

In summary, it can be concluded that while defense is provided for the plant by EFNs of both species, the details differ. The differences are certainly not surprising given the different habitats in which the two species are found. If the differences are real and not a product of unique events (such as the grasshopper "outbreak" of 1978) then the plasticity of response of Ipomoea EFNs to different types of plant damage is noteworthy. Defense of plant parts by ants appears to be a flexible interaction capable of utilizing diverse ant species and repelling various types of herbivores, depending on the circumstances.

\section{LITERATURE CITED}

Austin, D. F. 1975. Convolvulaceae. In R. E. Woodson and R. W. Shery [eds.], Flora of Panama. Ann. Mo. Bot. Gard. 62: 157-224.

BAKER, H. G., AND I. BAKer. 1973. Amino acids in nectar and their evolutionary significance. Nature 241: 543545.

- AND - 1975. Studies of nectar-constitution and pollinator-plant coevolution. In L. E. Gilbert and P. Raven [eds.], Coevolution of animals and plants, p. 100-140. Univ. of Texas Press, Austin. , P. A. OPler, AND I. BAKer. 1978. A comparison of the amino acid complements of floral and extrafloral nectaries. Bot. Gaz. 139: 322-332.

BAKer, I., AND H. G. BAKer. 1976a. Analyses of amino acids in flower nectars of hybrids and their parents, with phylogenetic implications. New Phytol. 76: 8798.

, AND

1976b. Analysis of amino acids in nectar. Phytochem. Bull. 9: 4-7.

Belt, T. 1874. The naturalist in Nicaragua. J. Murray, London.

Bentley, B. L. 1976. Plants bearing extrafloral nectaries and the associated ant community: interhabitat differences in the reduction of herbivore damage. Ecology 57: 815-820. 1977a. Extrafloral nectaries and protection by pugnacious bodyguards. Annu. Rev. Ecol. Syst. 8: 407-428.

- 1977b. The protective function of ants visiting the extrafloral nectaries of Bixa orellana (Bixaceae). J. Ecol. 65: 27-38.

DelpiNo, F. 1886-9. Funzione mirmecofile nel regno vegetale. Mem. R. Accad. Sci. Bologna. Serie 4. VII. 21-5-392; VII: 601-659; X: 115-147.

Elias, T. S., and H. Gelband. 1975. Nectar: its production and function in trumpet creeper. Science 189: 289-291.

INOUYE, D. W., AND O. R. TAYlor. 1979. A temperate region plant-ant-seed predator system: consequences of extrafloral nectar secretion by Helianthella quinquenervis. Ecology 60: 1-7.

JANZEN, D. H. 1975. Interactions of seeds and their insect predators/parasitoids in a tropical deciduous forest. In P. W. Price [ed.], Evolutionary strategies of parasitic insects and mites, p. 154-186. Plenum Press, New York.

KeEler, K. H. 1975. Plant adaptation: insect defense and enzyme variation. Ph.D. dissertation. University of California, Berkeley.

. 1977. The extrafloral nectaries of Ipomoea carnea (Convolvulaceae). Amer. J. Bot. 64: 1182-1188. -, AND R. B. KaUl. 1979. Morphology and distribution of petiolar nectaries in Ipomoea spp. (Convolvulaceae). Amer. J. Bot. 66: 946-952.

LiNSLEY, E. G. 1960. Observations in some matinal bees at flowers of Cucurbita, Ipomoea and Datura in desert areas of New Mexico and southeastern Arizona. J. N.Y. Entomol. Soc. 68: 13-20.

Picket, C. H., AND W. D. Clark. 1979. The function of extrafloral nectaries in Opuntia acanthocarpa (Cactaceae). Amer. J. Bot. 66: 618-625.

PIJL, L. VAN DER. 1954. Xylocopa and flowers in the tropics. K. Nederlandse AK Weters Proc. S7 Ser C: 413-423, 542-562.

SCHEMSKe, D. W. 1978. A coevolved triad: Costus woodsonii (Zingiberaceae) its dipteran seed predator and ant mutualists. Bull. Ecol. Soc. Amer. 59: 89.

Tilman, D. 1978. Cherries, ants and tent caterpillars: timing of nectar production in relation to susceptibility of caterpillars to ant predation. Ecology 59: 686-692. 